\title{
Multiple use, overlapping tenures, and the challenge of sustainable forestry in Alberta
}

\author{
by Craig Aumann ${ }^{1,2}$, Daniel R. Farr ${ }^{1}$ and Stan Boutin ${ }^{1}$
}

\section{ABSTRACT}

Public lands in Alberta are managed under the principle of multiple use. The two case-studies considered highlight the current and likely future impacts of this policy on forestry and other ecological values as development pressures continue to increase. Ultimately, sustainable forestry management in Alberta should not be about forestry policy alone, but a much broader land-use framework that embodies the principle of "envision-do-check-adapt."

Key words: multiple use, management policy, cumulative effects, petroleum development, land use, interdisciplinary, adaptive management

\section{RÉSUMÉ}

Les terres publiques de l'Alberta sont aménagées selon le principe de l'utilisation polyvalente. Les deux études de cas présentées soulignent les conséquences actuelles et vraisemblables de cette politique sur la foresterie et les autres valeurs écologiques tandis les pressions de développement continuent de prendre de l'ampleur. En fin de compte, l'aménagement forestier durable en Alberta ne devrait pas porter seulement sur les politiques forestières, mais devrait être un cadre de référence d'utilisation du territoire beaucoup plus étendu qui incorpore le principe de " vision, réalisation, vérification, adaptation ».

Mots clés : utilisation polyvalente, politique d'aménagement, effets cumulatifs, développement pétrolier, utilisation du territoire, interdisciplinaire, aménagement adaptatif

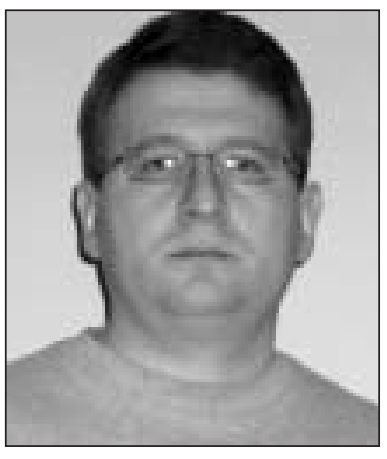

Craig Aumann

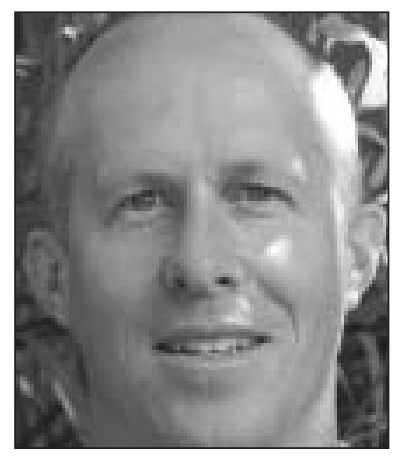

Daniel R. Farr

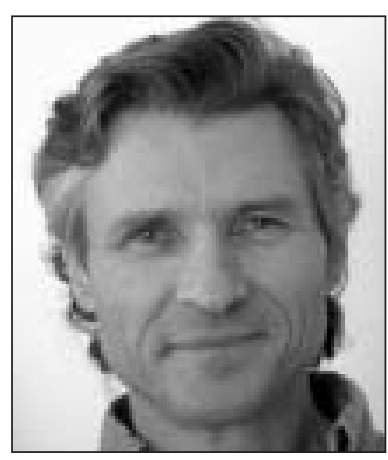

Stan Boutin

1999, Zhang 2005) and in some respects is a forerunner of ecosystem management (Vincent and Binkley 1993). While these two versions of multiple use differed with respect to the scale over which the objectives were to be achieved (region versus stand), both views share the idea that multiple use is about achieving particular goals or products from the landbase.

Another version of multiple use emerged around the

\section{The Meaning of Multiple Use in Alberta}

While multiple use is the dominant policy guiding land-use management decisions in Alberta, understanding the nature of this particular policy in Alberta requires differentiating among a number of alternative meanings for this term. Historically in both the US and Canada, multiple use meant the spatial separation of activities into separate geographic areas within a larger management region so that-across the entire region-products such as wood, water, forage, recreation and wildlife would be obtained (e.g., Chapman 1950, Behan 1967). By the 1960s, however, the "spatially segregated" multiple was out of favour and multiple use was about obtaining multiple products from the same stand via harmonious integration of separate industries (e.g., Gorte 1960s, which defined multiple use as a principle of management (USDA 1958). What is notable about this shift in meaning is that references to specific goals were dropped and multiple uses became an objective by itself (Behan 1967). Thus, the US Forest Service Manual (USDA 1958) states that "objectives are best accomplished by securing the highest degree of multiple use management that the character of the land will permit" without ever stating what objectives are to be accomplished. Similarly, the Public Lands Act in Alberta, while stating that land use is to be guided by the policy of multiple use contains no general purpose section, no general provisions setting out the principles that are to guide decisions, and no standards for the management of public lands as a whole, (Kennett 1998, Kennett and Ross 1998). Multiple use as a

\footnotetext{
${ }^{1}$ University of Alberta, Biological Sciences CW-405, Edmonton Alberta T6G 2E9.

${ }^{2}$ Present address: Alberta Research Council, 250 Karl Clark Road, Edmonton Alberta T6N 1E4. E-mail: craig.aumann@arc.ab.ca
} 
principle of management, rather than a statement about how multiple objectives would be achieved from a single landbase, thus comes closest to capturing the present meaning of multiple use in Alberta.

Since multiple use was taken as a principle of management, and since multiple use promised that the simultaneous development of all resources would - in aggregate-lead to higher outputs than the management of individual areas for single or dominant uses, Alberta attempted to achieve as many uses within each area as possible. Today, the uses existing within a single unit of land can include a quota holder's rights to a certain volume of a particular species of wood, forest management agreement (FMA) rights associated with other timber species, multiple petroleum companies can own the rights to extract petroleum from different geological strata (Alberta Energy 2005, 2006), multiple exploration companies can own the rights to perform surface exploration activities (Wenig and Kennett 2004), trappers can own trapping rights, ranchers can obtain leases for grazing cattle, and given that these are public lands the public generally has the right to use them for recreation. The history of these property rights on public lands indicates they are strong enough to provide a significant degree of security to companies or individuals seeking to invest, but weak enough to enable the government to adjust their nature through time or even cancel them (e.g., Murphy and Luckert 2002, Raymond 2003, Alberta Energy 2005).

When development pressures were relatively low in Alberta, the fault lines in this multiple use policy were barely visible, since the cumulative footprint was insufficient to impact other uses or ecosystem services. This paper examines some of the implications of this policy-primarily on forestry-when development pressures increase by a few orders of magnitude. The two case studies presented lead into a more general critique of multiple use policy and a discussion of the properties that a management system for public lands must have if it is to be successful under the current development pressures.

\section{Case Study 1 - Current and future impacts of petroleum devel- opment on the AIPac FMA}

The AlPac Forest Products FMA was formed in 1991 and is the largest FMA in the province, with its outermost boundary (Fig. 1) covering an area of approximately 7000000 hectares-encompassing a number of exclusions that are not part of the FMA. Since the 1960s, the primary petroleum disturbances occurring on this landbase were conventional natural gas exploration and oil-sands mining. As of late 2004, the total footprint associated with conventional natural gas was estimated to total approximately 230000 ha or just over 3\% of the area within the FMA's outer boundary (Aumann et al. 2005). Few regions of the FMA area contain no petroleum footprint, and such development is expected to continue into the future given that overall gas development in this region is presently estimated to be $50 \%$ to $60 \%$ complete (Mortensen et al. 2003). Across the entire Western Canada Sedimentary Basin, natural gas production is expected to peak in 2007, decline by $30 \%$ to $40 \%$ by 2015 , and by $53 \%$ to $66 \%$ by 2025 (Mortensen et al. 2003, National Energy Board 2004) implying that future land losses due to conventional natural gas will likely total another 100000 to 150000 ha given that some



Fig. 1. Location of the two case study areas relative to the province of Alberta. The first area represents the outer boundary of the AIPac FMA, while the second is the West-Central and East-Slopes area of the province which contains some 16 FMAs.

natural gas has been "shut-in" to facilitate bitumen extraction. The impacts of just conventional natural gas development on timber implied that current harvest levels were unsustainable over time (Schneider et al. 2003). The impacts of this existing development on woodland caribou, forest mammals, fish, and birds have also been documented (e.g., Dyer et al. 2001; Schneider et al. 2003; Bayne et al. 2004, 2005; Park, 2006; Habib et al. 2007). However, the future will see additional types of petroleum development that will have an even greater impact on both forestry and wildlife within this area.

The estimated volume of crude bitumen in place in Alberta as of 2002 is some 270 billion $\mathrm{m}^{3}$ (or $\sim 1.7$ trillion barrels). $80 \%$ of this volume is located in the Athabasca deposit (Fig. 2). Of this total in place volume, approximately $10.5 \%$ is currently recoverable either through open pit mining or Steam Assisted Gravity Drainage (SAGD) (AEUB 2006). To put this in context, Alberta's total recoverable oil reserves are the second largest in the world after Saudi Arabia 


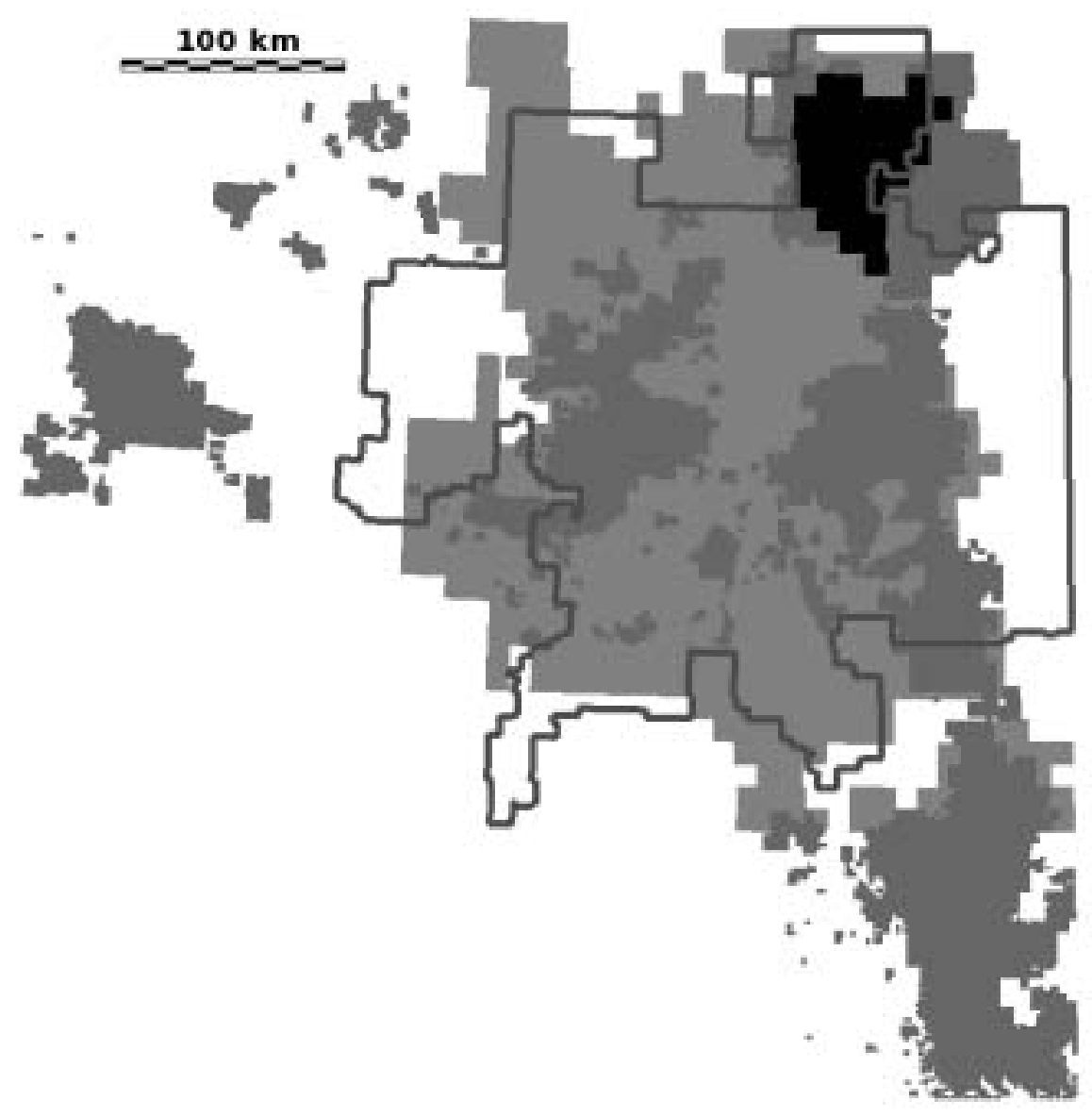

Fig. 2. The Athabasca bitumen deposit (light grey) is shown relative to AlPac's outer FMA boundary (black line). The black areas indicate where bitumen can be extracted using surface mining, while the darker grey areas indicate dispositions purchased for steam assisted gravity drainage (SAGD) as of early 2006. Most SAGD dispositions occurred in the last five years.

(Radler 2002, Dunbar et al. 2004) and less than 3\% of these recoverable reserves have been extracted (AEUB 2006).

The AlPac FMA is covered by most of the Athabasca deposit (Fig. 2). About half of the black area in Fig. 2 contains existing mining leases, with the majority of this area not yet under surface development. However, given that bitumen thickness is large throughout this black area (AEUB 2006), almost all of it can be expected to undergo open pit mining in the next several decades.

The darker grey areas in Fig. 2 indicate existing SAGD dispositions. Most of these areas are just beginning to be developed. The typical SAGD footprint is shown in Fig. 3 and consists of a central processing/steam generation facility, well sites, a network of pipelines and roads, exploratory wells, and 3D seismic lines that occur in a grid at a spacing of about 50 $\mathrm{m}$ (not shown). The lifespan of each facility is expected to be about 20 to 30 years. This footprint is expected to occur across all the existing SAGD lease areas in Fig. 2 and outside the existing lease areas, given that as of early 2006 not all areas with a large bitumen thickness are covered by dispositions (compare Fig. 2 to AEUB 2006 Fig. 2.3).

Existing forest loss just from conventional footprint is typically around $4 \%$, but can be as larger as $10 \%$, while losses from future SAGD and conventional development (excluding high density $3 \mathrm{D}$ seismic lines) result in an additional $5 \%$ to $8 \%$ loss over most of the SAGD area (Aumann et al. 2005). When features larger than $2 \mathrm{~m}$ in width (e.g., pipelines, roads, and conventional seismic lines) are buffered to account for their biotic impacts (Dyer et al. 2001), overall habitat loss reaches $30 \%$ to $40 \%$ and would approach $100 \%$ if $3 \mathrm{D}$ seismic lines less than $2 \mathrm{~m}$ wide were buffered and included in this calculation.

To reduce the cumulative petroleum and forestry impacts over its entire FMA, AlPac has been relatively successful at integrating its harvest actions with bitumen-related development by salvaging timber from areas slated for development. In 2006, such salvage harvests from just the SAGD area contributed approximately $30 \%$ of its total annual allowable cut (AAC) for its entire FMA. By 2010 it is projected that such salvage harvest will account for $50 \%$ of its $\mathrm{AAC}^{3}$ and that such levels will persist until about 2025 as current SAGD dispositions come into operation.

$\overline{{ }^{3} \text { Don Pope, Land Management Forester, ALPAC. Personal commu- }}$ nication, January 16, 2007. 


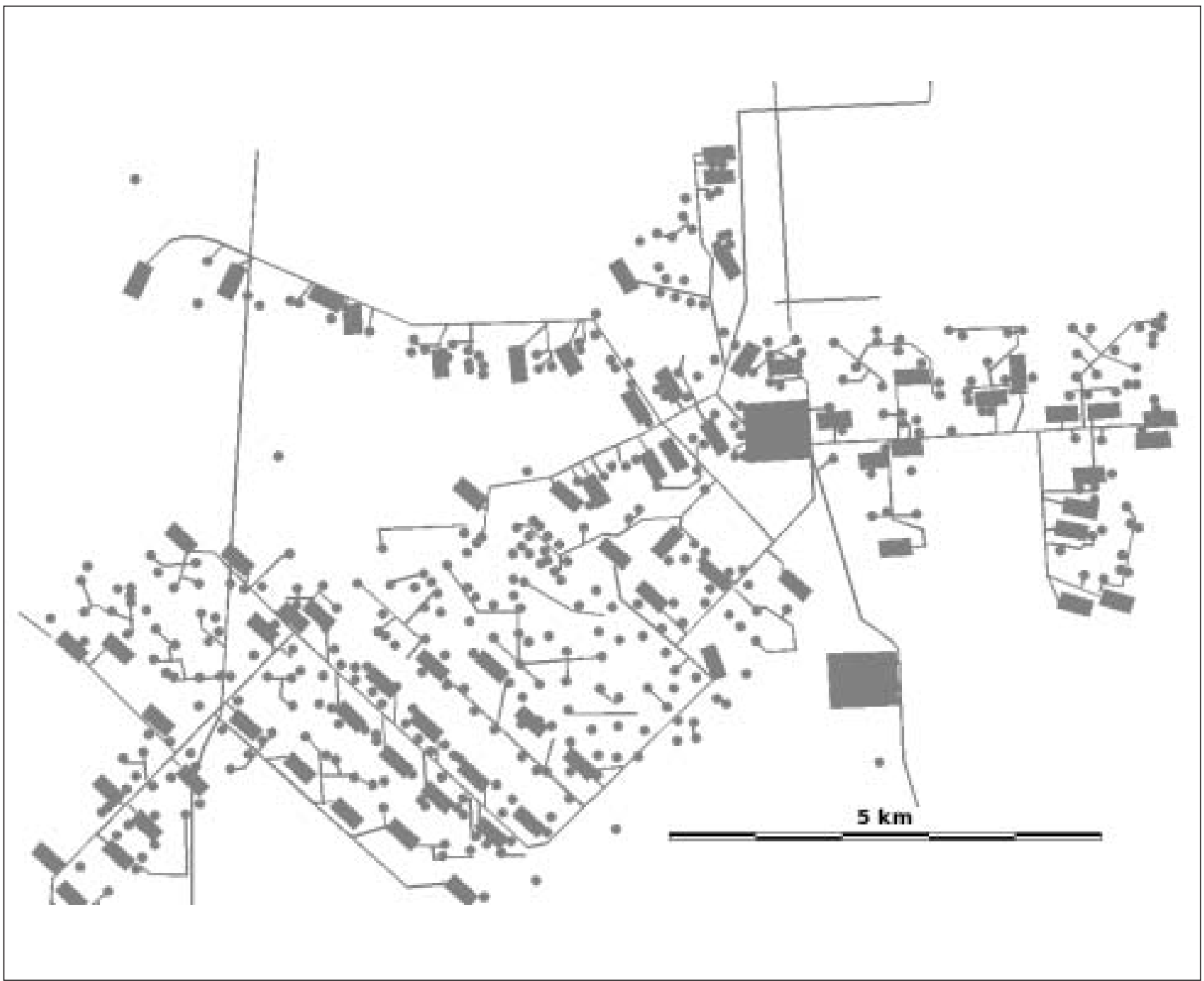

Fig. 3. Typical footprint intensity associated with SAGD development includes a central processing facility (large squares), well pads (medium-sized rectangles), observation wells (points), pipelines and roads. 3D seismic lines are not shown.

Peering even further into the future, SAGD is unlikely to be the only technology that will be used to extract bitumen, given that about $90 \%$ of the in-place reserves (most of which are located in less permeable "tight" sands or carbonate deposits) cannot be extracted economically using existing technology. Even if the lack of technology delayed such developments for 30 to 40 years, few SAGD areas would be fully reclaimed by that time. Because stands disturbed by petroleum development recover slowly to their former forest cover (e.g., Lee and Boutin 2006), such developments will represent a long-term deletion from the forest-producing landbase (Farr et al. 2004). Thus, not only will present salvage levels necessitate future reductions in timber harvest, but the associated large-scale loss of forested habitat in both the mineable and SAGD areas will also further impact forest-dependent species.

While such impacts may make some uncomfortable, the reality is that the economic returns associated with oil sands development are enormous. Between 2000 and 2020, oil sands-related developments are expected to generate $\$ 100$ billion in new investment to produce $\$ 532$ billion in upgraded crude bitumen production (assuming a conservative price of US \$32 per barrel) leading to a total increase in Canadian GDP across sectors of some $\$ 789$ billion, $\$ 634$ billion in Alberta alone (Timilsina et al. 2005). Given such economic returns, viewing multiple use as a principle of management devoid of explicit goals is certainly expedient as it eliminates the need to make difficult trade-off decisions among competing uses; however, these other uses will be severely impacted.

\section{Case Study 2 - The West-Central and East Slopes}

The West-Central and East Slopes Regions of the province (Fig. 1) contain numerous FMA areas ranging from less than 100000 ha to over 1000000 ha (see http://www.srd.gov. ab.ca/forests/managing/fma/companysummary.html). Besides forestry, conventional natural gas, conventional oil, and agricultural grazing have been the main land uses in this area. Cumulatively to 2006, this 9.8 million hectare area contains 43000 wells of all types, $216000 \mathrm{~km}$ of seismic lines 




Fig. 4. The remaining marketable conventional natural gas potential is shown relative to the West-Central and East slopes area (grey line, as in Fig. 1). Areas enclosed by the heavier black line have high coal-bed methane potential

and trails, $64000 \mathrm{~km}$ of pipelines, and about $24000 \mathrm{~km}$ of roads. However, relative to the rest of the province, this region has a very high remaining marketable natural gas potential (Fig. 4, and http://www.eub.ca/docs/documents/reports/ 2005-a-maps/Thm07.pdf), implying that the conventional natural gas development footprint will continue to grow in this region for some time with similar or even larger impacts to those described previously.

Millar Western Forest Products is one FMA in this region that has examined the impacts of such development on their wood-supply. Preliminary estimates suggest that cumulative volume losses due to petroleum will be approximately 50000 $\mathrm{m}^{3}$ or $12 \%$ of their AAC once all such development unfolds ${ }^{4}$. While this is a significant economic loss for this company, the reality is that such losses are insignificant in light of the far greater economic values achievable from petroleum development. Estimates made in 2003 for the Northern East Slopes region (a subset of the overall West-Central and East Slopes area) indicated oil and gas revenues exceed $\$ 8$ billion and represented $50 \%$ of all the revenues generated in this sub-region (Regional Steering Group 2003). Forestry and pulp revenues were approximately $\$ 1.8$ billion or just a quarter of petroleum revenues (Regional Steering Group 2003).

As in NE Alberta, a new future disturbance type will further impact this region. The Alberta Geological Survey estimates that there may be 2 trillion tonnes of coal at suitable depths for coal bed methane (CBM) exploration and some 14 trillion $\mathrm{m}^{3}$ of CBM gas in place (http://www.ags.gov.ab.ca/ activities/CBM/coal_and_cbm_intro.shtml). Given that

$\overline{{ }^{4} J o n a t h a n ~ R u s s e l l, ~ W o o d l a n d s ~ M a n a g e r, ~ M i l l a r ~ W e s t e r n ~ F o r e s t ~}$ Products Ltd., Personal communication, March 20, 2007.
CBM-related exploration is still in its infancy, these estimates will likely increase (http://www.csug.ca/). To put this estimate in context, Alberta's entire initial in-place conventional natural gas volume was approximately 7.8 trillion $\mathrm{m}^{3}$ (AEUB 2006) — or half the present estimates of CBM. However, while conventional natural gas produces a footprint of approximately one well per $\mathrm{km}^{2}$ with associated roads and pipelines, coal bed methane development produces around three wells per $\mathrm{km}^{2}$ along with associated roads and pipelines to service each well. Thus, the $12 \%$ loss in AAC reported above could more than double and the additional loss in habitat amount and quality will also further exacerbate wildlife responses in this region (e.g., Dzus 2001, Nielson et al. 2006).

\section{Critique of Current Multiple Use Policy}

The original idea of multiple use grew out of the Progressive Era in the early 1900s and was seen as a viable way of delivering Gifford Pinochot's "greatest good to the greatest number for the longest time." In the social context of that time, multiple use coupled with scientifically informed management was seen as a way to deliver this objective (Meine 2003). Science in those days was disciplinary, production-oriented and preecological and did not seek to provide much insight into systemic social, cultural, economic or environmental effects and is a world away from the current goals of ecosystem management that strive to be interdisciplinary, heterogeneous, and socially accountable with respect to ecological, economic and social values (e.g., Wang 2004). However, whether multiple use has been a failure in Alberta today depends on the particular definition adopted. When viewed strictly as a principle of management, the current policy has been a resounding success as illustrated by the many multiple overlapping uses occurring on the landbase. However, if viewed relative to the goals of sustaining timber and wildlife - two fairly minimal goals relative to the much broader goals of sustainable ecosystem management today - the policy is a failure. The practical effect of this duality has been to postpone critical evaluation of multiple use as method for management in Alberta. Indeed, Alberta has engaged in a number of previous initiatives to address land management issues resulting from multiple use (e.g., Hanson 1973, AENR 1983, Alberta Forestry 1991) that today are largely regarded as not being successful in delivering meaningful land-use reform (e.g., Walther 1987) in part because its politically challenging to let go of a policy predicated on the assumption that its possible to do everything, everywhere, all the time and avoid trade-offs. Blumm (1994) argues that the practical effect of the ambiguities inherent in the concept of multiple use will be that decision processes will favour well-organized and well-connected special interest groups relative to general public interests. Critics of previous land-use reform initiatives in Alberta have made similar observations (Kennett 2002, Davidson and MacKendrick 2004).

While the idea of multiple use has been critiqued in other contexts (e.g., Hall 1963, Blumm 1994), the emergence of concepts such as "integrated resource management" and "integrated landscape management" as ways of achieving harmonious integration among uses suggest that multiple use is still seen as viable. For example, one aspect of the broader integrated landscape management initiative started by the Alberta Chamber of Resources in 2000 focused on achieving 
greater integration between industrial users to reduce footprint creation. The success of this initiative resulted in the government of Alberta launching a provincial Integrated Land Management initiative in 2006 (http://www.srd. gov.ab.ca/). While integration and footprint reduction are certainly laudable, what has generally not been acknowledged is that even with best practices such integration may not be sufficient to enable achievement of other management goals. For example, footprint reductions in the two case studies above will be totally swamped by the huge increases in development so that total timber and habitat losses will still increase dramatically. Reducing the rate of cumulative footprint development on the landscape through integration only guarantees that the future landscape will have less disturbance than it would have without such best practices. While this is certainly positive, overall development pressures and rates still need to be considered to determine if such reductions are sufficient for achieving other goals. As a policy, multiple use is inadequate because it fails to consider the limits inherent in harmonious integration under intense development pressures and offers no practical suggestions about what to do when integration alone is inadequate.

Perhaps the most fundamental problem with current multiple use is that it either fails to require clear and enforceable goals that could guide decision-making, or considers only a small set of goals that are insufficient relative to the current broader goal of ecosystem-based management (Kennett 1998). Without goals, almost any decision can be construed as being in the public interest. Even the versions of multiple use that are supposedly about achieving a small number of objectives such as timber, water, wildlife, recreation, and grazing are woefully inadequate because the concept does not require the user to specify the spatial and temporal scales over which such objectives are to be achieved. Without such specification, it is difficult to say whether management decisions are actually successful. Other inadequacies of multiple use are that it makes no reference to the social and political processes associated with setting management goals, does not acknowledge the political implications of making trade-off decisions among competing uses, provides no alternatives beyond integration and (possibly) spatial segregation for achieving management goals, and in practice fails to acknowledge that setting goals implies capping cumulative effects.

\section{Addressing the Current Land Management Challen- ges in Alberta}

To address the challenges of managing the public and private lands in Alberta, the government is currently engaged in a public consultation process around a new Land-Use Framework for the province (http://www.landuse.gov.ab.ca/). This framework certainly has the potential to address a wide range of land management issues by defining a new vision for moving beyond multiple use as a principle of management. Based on the failings of current multiple use policy, it is worth identifying what attributes this framework must possess to be successful under current development realities.

Ultimately, a new management system needs to be about goals and the spatial and temporal scales over which these goals are to be achieved. Focusing on goals immediately raises two questions: who chooses the goals and how does one assess whether the goals are being achieved? In terms of the first question, Norton (2005) has argued that goal-setting needs to be a public process so that the goals reflect the public's economic, ecological and social values.

Determining whether the goals are being achieved requires ongoing monitoring across appropriate spatial scales using indicators that are relevant for determining goal achievement. During the Progressive era of the early 1900s, monitoring was seen as superfluous because of the great optimism placed in the power of science and rational planning to solve any management problem (Hays 1959, Nelson 1995). Today we are more inclined to see ecosystems and the relationship between society and nature as being not only more complex than we think, but possibly even more complex than we can think (Jeffrey and Gearey 2006, Pahl-Wostl 2007) and thus acknowledge the need for monitoring and adaptation given that we are unlikely to ever find the perfect policy. The attributes monitoring programs must have to be effective are also well understood. Effective monitoring programs must be quasi-independent bodies from both government and stakeholder groups, with independent sources of funding (such as endowments) to ensure the program is not stopped due to budget cutbacks or other political reasons. Second, monitoring must also be about reporting and communicating and not simply collecting data. While Alberta has made much progress in developing and implementing a cost-effective program for monitoring and reporting on biodiversity (e.g., Stadt et al. 2006, http://www.abmp.arc.ab.ca), effective monitoring and reporting for other goals (e.g., air and water quality) will require the development of similar programs.

The results from ongoing monitoring and reporting must feed into the decision-making process. Presently in Alberta, few legal and regulatory mechanisms exist to facilitate interministry coordination for making decisions about the cumulative impacts across a single landbase (Ross 2002). Achieving such integration will require structural integration of the entire policy and legislative framework for resource and environmental decision-making (Kennett 2002, 2006) and transitioning from the current reality of autonomous sectorial decision-making within each ministry, to the reality of an integrated management approach under which separate sectors make single, integrated decisions (Walther 1987). Such a transformation will require the development of a new legal and policy framework.

In summary, the essence of what we are suggesting is that Alberta remove multiple use as a principle of land management and substitute it with the principle of "envisiondo-check-adapt." Goals, indicator frameworks, and ongoing monitoring that feeds directly into a decision-making process are the "infrastructure" needed to effectively evaluate the efficacy of any policy that might be implemented and enable adaptation to new emerging realities. This framework is distinct and separate from the policies adopted to achieve the desired goals.

Two alternative policies that are currently being evaluated include priority land-use zoning and tradable land-use credits and involve different ways of enforcing caps on overall disturbance within a region. In priority land-use zoning, different areas are zoned for alternative types and levels of development-similar to zoning in cities or municipalities. A potential advantage of priority land-use zoning is that SAGD areas would no longer require detailed forest management plans nor would each separate SAGD facility need to go through a full EIA process, while areas zoned for achieving wildlife or 
watershed protection would have quite different acceptable disturbance limits and EIA requirements. However, given that any unit of the landbase generally contains many existing dispositions, the financial impacts associated with implementing such a zoning strategy may be insurmountable. Tradable landuse credits are a way to overcome this barrier. By capping the amount of disturbance and making the right to disturb habitat a tradable commodity, current disposition holders would have to purchase disturbance credits in a market if they want to proceed with development. As a given developed area recovers, the holder of the land-use credit can sell the credit on the market, enabling development somewhere else. In this way, limits on disturbance are maintained, existing dispositions are respected, and the greatest economic returns obtained while still respecting other goals. A possible disadvantage is that industries producing lower economic returns could be shut out of the market. The best policy may blend priority zoning with tradable land-use credits.

The evaluation of priority zoning and tradable land-use credits is occurring using a variety of landscape simulation models. The key point is that before policies are implemented, they should be evaluated using landscape simulation models. The failure of multiple use under intense development pressures is a sobering lesson in what is required of policy assessment. While multiple use could (sort of) cope under the development pressures of the 1970s, few questioned how this policy might perform if development increased by a few orders of magnitude. Given the enormous regulatory efforts associated with implementing any new policy, and given that some policies will perform better than others, we only want to spend our efforts implementing the best possible policies. This requires evaluating policies using a variety of landscape simulation models, under a variety of alternative possible futures, and reporting on performance with the same indicator framework used for ongoing monitoring. If the relationship between society and nature is indeed more complex than humans can comprehend, then we will have to be content with implementing the best policy resulting from such model-based evaluation and relying on monitoring to verify whether the policy is indeed enabling us to achieve the desired goals.

While this basic adaptive management framework outlined above is certainly not new, much work remains in implementing many of the components listed in the context of land-use management. While some work has been done on effective processes for public consultation about the goals and thresholds for landscape performance (e.g., Parkins and Mitchell 2005, Beckley et al. 2006), more work is certainly needed. Similarly, more work is needed on indicator frameworks that can be used for both actual landscapes and simulation modeling (e.g., Olsson et al. 2006). On the legal side, implementing a framework in which the principle of "envision-do-check-adapt" is legally meaningful, or in which policies such as priority land-use zoning or tradable land-use credits are implemented requires substantial changes in existing statutes and policies. Finally, while land-use simulation models play a central role in enabling evaluation of alternative policy options, the challenge is that tools with all desired capabilities currently do not exist and need to be developed (e.g., Verburg et al. 2004, Couclelis 2005).
In summary, the fundamental challenge of overcoming the problems inherent in current multiple use policy in Alberta (and other jurisdictions) is that it requires solutions to a suite of complex problems that jointly inhabit a space that is not within the purview of traditional forestry sciences, or indeed any discipline. Perhaps the interdisciplinary challenges of integrated management explain why so little progress has been made over the last 100 years in understanding the steps and conditions necessary for its successful implementation (Mitchell 1986, Born and Sonzogni 1995, Margerum 1999, Jeffrey and Gearey 2006). Thus, we reach the conclusion (unsettling perhaps to some readers of this journal) that achieving sustainable forest management in Alberta is not just about forest policy, but a much broader land-use management framework that moves beyond the current policy of multiple use.

\section{Acknowledgements}

While the views expressed in this paper are solely those of the authors, we wish to acknowledge Bob Demulder, Don Pope, and the anonymous reviewers for their critical comments on an earlier version.

\section{References}

Aumann, C., W.A. Kurz, S. Boutin and B. Stelfox. 2005. Modeling petroleum development and forestry harvest on the AlPac FMA: implications for ecological management. Technical Report, Dept of Biological Sciences, University of Alberta. 147 p.

Alberta Energy. 2005. Alberta's oil and gas tenure. Alberta Department of Energy, Edmonton, AB [online]. Available at http://www.energy.gov.ab.ca.

Alberta Energy. 2006. Alberta oil sands tenure guidelines: principles and procedures. Alberta Department of Energy, Edmonton, AB [online]. Available at http://www.energy.gov.ab.ca.

Alberta Energy and Natural Resources (AENR). 1983. A system for integrated resource planning in Alberta. Energy and Natural Resources, Resource Evaluation and Planning Division, Edmonton. 25 p.

Alberta Energy and Utilities Board (AEUB). 2006. Alberta's energy reserves 2005 and supply/demand outlook 2006-2015. Alberta Energy and Utilities Board, Calgary, AB. 150 p. Available at http:// www.eub.gov.ab.ca.

Alberta Forestry. 1991. Integrated resource planning in Alberta. Forestry, Lands and Wildlife, Resource Planning Branch, Edmonton, AB. 21 p.

Bayne, E.M., S. Boutin and R. Moses. 2004. Are boreal forest mammals good indicators of cumulative effects? Sustainable Forestry Management Network, Project Report.

Bayne, E.M., S.L. Van Wilgenburg, S. Boutin and K.A. Hobson. 2005. Modeling and field-testing of ovenbird (Seiurus aurocapillus) responses to boreal forest dissection by energy sector development at multiple spatial scales. Landscape Ecology 20(2): 203-216.

Beckley, T.M. J.R. Parkins and S.R.J. Sheppard. 2006. Public participation in sustainable forest management: A reference guide to best practices. Knowledge Exchange and Technology Exploitation (KETE) programme of the Sustainable Forest Management Network, Edmonton, AB [online]. Available at http://www.sfmnetwork.ca/docs/e/SR_200506beckleypub_en.pdf.

Behan, R.W. 1967. The Succotash Syndrome, or multiple-use: a heartfelt approach to forest land management. Natural Resources Journal 7(4): 473-484.

Blumm, M.C. 1994. Public choice theory and the public lands: why 'multiple use' failed. Harvard Environmental Law Review 18: 405-432. 
Born, S.M. and W.C. Sonzogni. 1995. Integrated environmental management: strengthening the conceptualization. Environmental Management 19(2): 167-181.

Chapman, H.H. 1950. Forest Management. Hildreth Press, Bristol, CT. Couclelis, H. 2005. "Where has the future gone?" Rethinking the role of integrated land-use models in spatial planning. Environment and Planning A 37: 1353-1371.

Davidson, D.J. and N.A. MacKendrick. 2004. All dressed up with nowhere to go: the discourse of ecological modernization in Alberta, Canada. The Canadian Review of Sociology and Anthropology 41(1): 47-65.

Dunbar, R.B., M. Strogran, P. Chan and K. Chan. 2004. Oil sands supply outlook: potential supply costs of crude bitumen and synthetic crude oil in Canada. Canadian Energy Research Institute, Calgary, AB. 190 p.

Dyer, S.J., J.P. O'Neill, SM. Wassel and S. Boutin. 2001. Avoidance of industrial development by woodland caribou. Journal of Wildlife Management 65(3): 531-542.

Dzus, E. 2001. Status of the Woodland Caribou (Rangifer tarandus caribou) in Alberta. Alberta Environment, Fisheries and Wildlife Management Division, and Alberta Conservation Association, Wildlife Status Report No. 30, Edmonton, AB. 47 p. Available at http://www.srd.gov.ab.ca/fishwildlife/status/pdf/caribou.pdf

Farr, D., S. Kennett, M.M. Ross, B. Stelfox and M. Weber. 2004. Conserving Canada's Natural Capital: The Boreal Forest. Al-Pac Case Study Report. Prepared for the National Round Table on the Environment and Economy [online]. Available at http://www.nrteetrnee.ca/eng/programs/Current_Programs/Nature/BorealForest/Documents/200407-AlPac-Case-Study/200407-AlPac-CaseStudy_Contents_E.htm

Gorte, R.W. 1999. Multiple use in the national forests: Rise and fall or evolution? Journal of Forestry 97(10): 19-23.

Habib, L., E.M. Bayne and S. Boutin. 2007. Chronic industrial noise affects pairing success and age structure of ovenbirds Seiurus aurocapilla. Journal of Applied Ecology 44(1):176-184.

Hall, G.R. 1963. The myth and reality of multiple use forestry. Natural Resources Journal 3: 276-290.

Hanson, W.R. 1973. History of the Eastern Rockies Forest Conservation Board, 1947-1973. Eastern Rockies Forest Conservation Board, Calgary, AB. 58 p.

Hays, S.P. 1959. Conservation and the gospel of efficiency: the progressive conservation movement, 1980-1920. Harvard University Press, Cambridge, MA. 297 p.

Jeffrey, P. and M. Gearey. 2006. Integrated water resources management: lost on the road from ambition to realisation? Water Science and Technology 53(1): 1-8.

Kennett, S.A. 1998. New Directions for Public Land Law. Canadian Institute of Resources Law, University of Calgary, Calgary, AB. 51 p. Available at http://www.cirl.ca/pdf/OP04Directions.pdf.

Kennett, S.A. 2002. Integrated resource management in Alberta: past, present and benchmarks for the future. Canadian Institute of Resources Law, University of Calgary, Calgary, AB. 35 p. Available at http://www.cirl.ca/pdf/OP11Benchmarks.pdf.

Kennett, S.A. 2006. A checklist for evaluating Alberta's new land-use initiatives. Resources \#95. Canadian Institute of Resources Law, University of Calgary, Calgary, AB. Available at http://www.ucalgary.ca/ cirl/pdf/Resources95.pdf.

Kennett, S.A. and M. Ross. 1998. In search of Public Land Law in Alberta. Canadian Institute of Resources Law, University of Calgary, Calgary, AB. 56 p. Available at http://www.cirl.ca/pdf/OP05Search. pdf.

Lee, P. and S. Boutin. 2006. Persistence and developmental transition of wide seismic lines in the western Boreal Plains of Canada. Journal of Environmental Management 78(3): 240-250.

Margerum, R.D. 1999. Integrated environmental management: the foundations for successful practice. Environmental Management 24(2): 151-166.
Meine, C. 2003. Ch. 11, Conservation and the progressive movement: growing from the radical center, In B.A. Minteer and R.E. Manning (eds.). Reconstructing Conservation: Finding Common Ground. pp. 165-184. Island Press, Washington, DC.

Mitchell, B. 1986. The evolution of integrated resource management. In R. Lang (ed.). Integrated approaches to resource planning and management. pp. 13-26. Banff Centre School of Management, University of Calgary Press, Calgary, AB.

Mortensen, P., M. Foss, B. Bowers and P. Miles. 2003. Potential supply and costs of natural gas in Canada. Canadian Energy Research Institute, Calgary, AB. 97 p.

Murphy, P.J. and M.K. Luckert. 2002. The Evolution Of Forest Management Agreements On The Weldwood Hinton Forest, The Foothills Model Forest History Series, Volume 3. Foothills Model Forest, Hinton, AB. 252 p. Available at http://www.fmf.ab.ca/ AFM/AFM_Vol3.pdf.

National Energy Board. 2004. Canada's oil sands: opportunities and challenges to 2015, National Energy Board, Calgary, AB. 158 p. Available at http://www.neb-one.gc.ca/clf-nsi/rnrgynfmtn/nrgyrprt/lsnd/pprtntsndchllngs20152004/pprtntsndchllngs20152004eng.pdf.

Nelson R.H. 1995. Public lands and private rights: the failures of scientific management. Rowman \& Littlefield, Lanham, MD. 373 p.

Nielsen S.E., G.B. Stenhouse and M.S. Boyce. 2006. A habitat-based framework for grizzly bear conservation in Alberta. Biological Conservation 130(2): 217-229.

Norton, B.G. 2005. Sustainability: a philosophy of adaptive ecosystem management. University of Chicago Press, Chicago, IL. 607 p. Olsson, A.J., I. Theesfeld, C. Schleyer, D. Cairol, N. Turpin, et al. 2006. A restricted package of definitions of indicators and operational methodologies to assess them - to be implemented in Prototype no. 1 and suggestions for the future developments of indicatorsin SEAMLESS. Report No. 22, SEAMLESS Integrated Project, EU 6 Framework Programme. 183 p. Available at http://www. seamless-ip.org/Reports/Report_22_D2.1.1.pdf.

Pahl-Wostl, C. 2007. The implications of complexity for integrated resource management. Environmental Modelling and Software 22: 561-569.

Park, D.J. 2006. Stream fragmentation by hanging culverts along industrial roads in Alberta's boreal forest: assessment and alternative strategies. M.Sc. Thesis, University of Alberta, Edmonton, AB. 97 p. Parkins, J.R. and R.E. Mitchell. 2005. Public participation as public debate: a deliberative turn in natural resource management. Society and Natural Resources 18(6): 529-540.

Radler, M. 2002. Worldwide reserves increase as production holds steady. Oil and Gas Journal 100: 113-145.

Raymond, L. 2003. Private rights in public resources: equity and property allocation in market-based environmental policy. Resources For the Future, Washington, DC. 252 p.

Regional Steering Group. 2003. The Northern East Slopes Sustainable Resource and Environmental Management Strategy: Recommendations to the Minister of Environment. Pub No 1/946, Alberta Environment, Edmonton, AB. Available at http://www3. gov.ab.ca/env/regions/nes/pdfs/NES_Strategy_Final_May_2003.pdf. Ross, M.M. 2002. Legal and institutional responses to conflicts involving the oil and gas and forestry sectors. Canadian Institute of Resources Law, University of Calgary, Calgary, AB. 38 p. Available at http://www.cirl.ca/pdf/OP10Conflicts.pdf.

Schneider, R.R., J. B. Stelfox, S. Boutin and S. Wasel. 2003. Managing the cumulative impacts of land uses in the Western Canadian Sedimentary Basin: a modeling approach. Conservation Ecology 7(1):8 [online]. Available at http://www.consecol.org/vol7/iss1/art8/ Stadt, J.J., J. Schieck and H.A. Stelfox. 2006. Alberta biodiversity monitoring program - monitoring effectiveness of sustainable forest management planning. Environmental Monitoring and Assessment 121(1-3): 33-46. 
Timilsina, G.R., N. LeBlanc and T. Walden. 2005. Economic impacts of Alberta's oil sands. Canadian Energy Research Institute, Calgary, AB. 105 p.

U.S. Department of Agriculture (USDA). 1958. Forest Service Manual. U.S. Department of Agriculture, Forest Service.

Vincent, J.R., and C. S. Binkley. 1993. Efficient multiple-use forestry may require land-use specialization. Land Economics. 69(4):370-376.

Verburg, P.H., P. P. Schot, M. J. Dijst and A. Veldkamp. 2004. Land use change modelling: current practice and research priorities. GeoJournal. 61: 309-324.

Walther, P. 1987. Against idealistic beliefs in the problem-solving capacities of integrated resource management. Environmental Management 11(4): 439-446.
Wang, S. 2004. One hundred faces of sustainable forest management. Forest Policy and Economics 6: 205-213.

Wenig, M.M. and S.A. Kennett. 2004. The legal and policy framework for managing public access to oil and gas corridors on public lands in Alberta, Saskatchewan, and British Columbia: research report prepared for the Canadian Association of Petroleum Producers, Canadian Institute of Resources Law, Calgary, AB. 141 p. Available at http://www.capp.ca/raw.asp?NOSTAT=YES\&dt=PDF $\& d n=77025$.

Zhang, Y. 2005. Multiple-use forestry vs. forestland-use specialization revisited. Forest Policy and Economics 7: 143-156. 